\title{
EXGATED: INTERVENTION TO MITIGATE THE IMPACT OF THE MEXICAN GATED COMMUNITIES OVER TERRITORIES AND CITIES
}

\author{
TANIA ASCENCIO-ANAYA, MARTHA CAUDILLO-PLASCENCIA, \\ ERNESTO RAMÍREZ-GARCÍA \& EMANUELE GIORGI \\ Tecnologico de Monterrey, Escuela de Arquitectura, Arte y Diseño, Mexico
}

\begin{abstract}
The controlled access developments have become the most popular way of living for the vast majority in Mexico. The increasing wave of insecurity is supposedly one of the main factors that causes the demand of these model of settlements. The proposed research focuses on distinguishing the different features and problematics that can be found in this kind of neighborhoods. The investigation takes as main frame the gated communities and the implications they have on cities, societies, cultures and citizens. For the purposes of this investigation, it is considered as "gated community" any neighborhood with restricted entry, security personnel and surrounding walls. In León, Guanajuato (Mexico), where the investigation takes place approximately the $30 \%$ of the whole consolidated area of the city is currently occupied by closed communities. A significant number of them is located all around the periphery of the municipality. The conflicts generated by the controlled access communities in León are plenty: the most notorious ones are the social polarization and the increasing of dependency on motorized transit to get around. In fact, the segregation of the neighborhoods interrupts roads and prevents communication between different parts of the city. The goal of the research is to get to a point of understanding the state of the art of the relation between city, communities and closed neighborhoods. Afterwards, the proposal of a radical physical set of interventions to mitigate the current problems is presented. The methods to obtain relevant information to nourish the research were varied: from the analysis of local papers, articles and study cases, to qualitative social research, acknowledging the diverse perspectives that people from distinct backgrounds and neighborhood could have about the phenomenon of Mexican gated communities.
\end{abstract}

Keywords: gated communities, Mexico, urban gating, unlocking communities, right to the city.

\section{INTRODUCTION}

The UN-Habitat defined that gated communities share a series of features, such as "separation from neighboring land by fences, walls, or by other constructed or natural obstructions, including symbolic barriers; and filtered or selective entry using mechanical, electronic or human guardianship as access-control elements" [1]. Mexico possess one of the highest concentrations of these settlements [2]. The relevance of this problematic transcends way beyond the physical implications in mobility, the expansion of the urban sprawl and the invasion of natural spaces [3]. In addition, the built reality has an effect on the mental and psychological sphere. The population that lives inside as well as the one that lives outside are affected equally. The fear and resentment both parties perceive promote the use of security corps, and this encourages an environment that generates discrimination and hatred between social and economic classes [4] perpetuating the cycle of this social conflict.

León is one of the main metropolitan areas in México. It has an area of 22,473 hectares [5]. The research focuses in the north zone of this locality where almost a third of the territory that makes up this area has been privatized [6]. There is a presence of "303 neighborhoods of which 80 are restricted access communities" [6] (Fig. 1). In comparison, the second largest metropolis in México - Guadalajara - owns "2,500 clusters or closed urbanizations - that extend over 14 percent of the 65,000 hectares of the built city" [7]. 


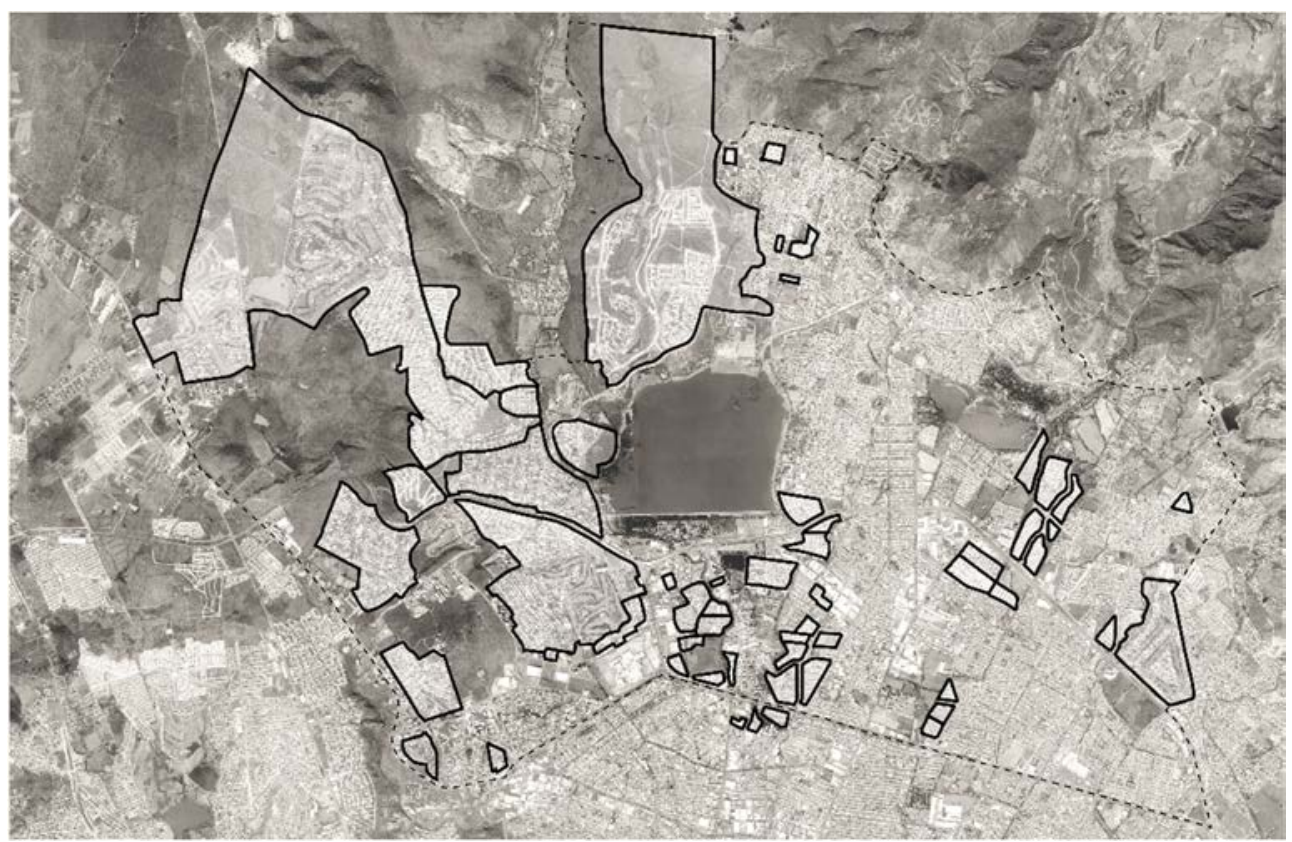

Figure 1: Satellite view of the North Zone of León with marked gated communities.

The conclusions drawn up to this point are: firstly, León has a higher agglomeration of gated neighborhoods, and secondly, the size of these communities are larger and vaster than those in Guadalajara in order to congruently reflect these figures.

The path taken to understand the state of the art of the urban gating [2] in León was intricate and not linear. The selection of one cluster - with the most complicate situation for the design proposal, faced the fact that there is not an existent method to size this. The lack of parameters to measure the level of gatedness and also the inside-out and intern impact in both physical and social matters gave guidelines for the development of different tools to evaluate the conditions of these private neighborhoods. Moreover, the acknowledgement of the causes that led to these sort of urbanizations where varied and not consistent, unlike the consequences. The latter follow a similar pattern usually tending to tangible issues, such as conflictive mobility and irregular occupation, and also sociological matters, like polarization and segregation. The empirical, fact-based approach, compared to a more philosophical and theoretical one aid the research to complement, collate and link diverse perspectives to build a comprehensive and general reason to the problematic.

It is possible to tackle the causes and the symptoms at once. The plan focuses in promoting an open city plan with an inclusive and heterogeneous urban system and a diverse and connected mobility network. Urban areas must not reflect the darkest side of the human being but places where happiness and joy are always achievable. A truthful right to the city is vital in order to confront other problematics in the social, cultural, economic, and physical fields.

\section{WHERE DOES IT START, WHERE DOES IT END?}

The primary step for the elaboration of the proposal was to identify and comprehend the causes that have promoted the privatization of León. Afterwards, the method was to list and classify all the effects this problematic provoke in different topics. Assess the implications 
of these effects and their impact on agents and stakeholders involved. Ultimately, present a set of strategies to counteract not only the effects of the urban gating but attack the main origins of it. The research served the purpose to collect different, yet obvious stances, and develop a justified criteria in the transformation of the city. It is important to mention that many initial observations and perceptions of the research team conducted the investigation to prove right or wrong these viewpoints. The reasons and consequences presented on the following paragraphs attempt to categorize the diverse topics to be presented in a more organized and logical manner.

\subsection{Physical and economic causes}

The appropriation of large sized parcels to develop communities for the most affluent social classes has become the standard in Mexico. Since the eighties, the consolidated growth that has been occurring in the city has been taking two ways. The urbanization around peripheral and underdeveloped roads, and the occupation of distant areas of high scenic and ecological value [3], [8]. The process of dwelling in peripheral zones are nurtured by the desire of inhabitants to be surrounded by nature and green spaces without the incommodities of consolidated cities [3]. Another cause is the outstanding success the business model has showed. As declared by Cabrales [9], the gated communities and the vertical luxury condominiums have become the most successful real estate product of recent times. The latter has been the main motive for developers to invest in these projects.

\subsection{Sociological and psychological causes}

The tendency of past generational groups to own a suburban residence [4], was a complementary reason to this growth. The offer of exclusivity, the perception of security, and the aspirational lifestyle promote the wish of the population to acquire a product with a supposed constant capital gain [9], which provides status, and differentiates themselves from the rest. The existence of a deep and ingrain unconscious drive of polarization and social segmentation is participant in the emergence and perpetuation of the conflict. Low [10] stated that "the walls are making visible the systems of exclusion that are already there, now constructed in concrete". Under a rhetorical discourse of fear, this class-based exclusion appears as a rational solution [10]. Furthermore, it has been pointed out that there are certain singularities that make local municipalities to adopt and even endorse the creation of these compounds. "The lack of planning expertise, limited budgets, short-term government periods, incapacity to provide adequate public services and infrastructure, lack of intergovernmental cooperation, and strong pressure from developers" [11] join the cause. "Gated communities have been received by local authorities as a "convenient" arrangement, since developers take responsibility to provide basic infrastructure and services, residents can assume private management responsibilities for maintenance, administration, and security, and these developments represent higher tax income. Therefore, local governments have directly and indirectly supported the proliferation of these housing developments with private governments" [11].

From a sociological viewpoint there is a strong bond between the speculative neoliberalism, the failed attempt of a social state, the individualism, the indifference and the lack of social consciousness [12]-[14]. However, recognizing the three actors involved in the equation: the private investment, the public administration and the will of the population, it is easy to relate that each one stimulates the others. It becomes a cycle in which all are reason and effect. On the one hand the conversion of the land into a commodity boosts projects with 
greater earnings over the ones that seek for an urban planning agenda [3]. On the other hand, local governments recognize their disability to assure certainness and instead looks forward that people look alone their own personal solutions to problems produced by the whole society [13].

\subsection{Urban consequences}

León like many cities in central Mexico has a notorious absence of vegetated areas. It owns a coefficient of 5.17 square meters per inhabitant [5]. This ratio is only diminishing as more gated neighborhoods and car-oriented infrastructure appropriate natural spaces. Likewise, if it is considered the amount of green areas that are currently privatized the degree is even more alarming. The residential segmentation is another key conflict. Even though different social groups end up occupying lands next to each other, the procedures of polarization become more evident. "On a large scale we can highlight a process of social mixing, while at the micro level the segregator pattern is reinforced" [3]. These facts come together to strengthen a car dependent reality. This is simply explained by Owen [15] "what you actually do when you move out of the city is move into a car". The result is a city with a conflictive mobility and an unsatisfactory air quality that is often in an environmental pre-contingency state [16]. "The forecast for the city in 2030 is a challenge: lack of spaces for citizens, lack of connectivity and lack of road infrastructure" [17]. Tun [18] presented the urban dispersion that has been happening in the city. While there was a population increase of $71 \%$, the AGEB density decreased from 4,399 inhabitants in 1990 to 2,724 in 2010. If it is considered that the city will have a growth from 1,578,626 in 2015 to 1,743,000 inhabitants in 2030 [17] it is expected that the density ratio continues falling [19]. If the city remains expanding the city would face a financial bankruptcy and the security would become more complex [19].

\subsection{Social consequences}

It is true that the discourse of fear and the rise of violence in the country fueled the residential exclusion [3]; nevertheless, it should be noted that the reaction has the duality of being the cause simultaneously. The inequality of opportunities has shown to be the reason of criminal increase and sense of insecurity [3]. Additionally, the feeling of hostility [2] indifference, contempt and envy [3] as well as the poverty [17], [18] are relative to the locking of the city. Similarly, developers and dwellers of gated communities end up feeling entitled and with the right to decide over cities. These urban managers assume the roles of local governments [11]. In advanced cases of segregation - such as Alphaville, Sao Paulo - all the culture, the government, the inhabitants and the lifestyles are replaced inside the walls with a parallel and detached city [4]. The physical changes in the urban features end up transforming the social life in every sphere.

The city exclusion is not a factor that only impacts diverse socioeconomic sectors but also people from diverse demographic groups, such as infants, the elderly, and persons with reduced mobility. In the investigation area there are about 247,433 residents from which about 85,281 - around the $34.47 \%$ - [20] represent the individuals without the capacity to drive and get around by themselves. It is becoming more common to accept many of these problematics as the status quo; nonetheless, it is crucial to present solutions that are not biased by economic interests, hostility [2], and fear [10]. The social structure has been broken. "This can be seen in the current cities where division and privatization of much of the city's living space, discourages the use of public space, causing a social discontent that can translate into crime, insecurity and violence of all kinds" [17]. 


\section{EVALUATION TOOLS}

As previously mentioned, due to the troublesome to measure gatedness and urban impact it was needed to realize a series of tools that could ease the process. Ferreti and Arreola [8] showed a set of variables that serve as indicators of the quality of the urban fabric including: "tissue permeability, frontality of the architectural type, community spaces/interstices, urban fissures, and border pressures". The latter marked a path in the development of the urban impact tool. For the creation of the gatedness tool it was initially needed a qualitative approach mainly because of subjective factors like insecurity and the perception of it. Just as Low [10] found, the desire to live inside a controlled access area does not fully relate to the safety of it rather the conditioning, acceptance and replicability of its dwellers. When people decide to live in a gated community it becomes difficult and unlikely to go back to the open city [10]. The level of gatedness of any neighborhood strongly influences other social matters.

\subsection{Gatedness evaluation tool}

This tool consists of two main procedures. A quantitative one that assigns values to variables such as: settlers association, controlled access, documented controlled access, existence of security corps, physical enclosure, multiple physical barriers, maintenance fee, and utilization of CCTV and the use of technology appliances to regulate the entry. In addition; interviews conducted to internal and external dwellers to collate qualitative factors. Some of them are the impact their everyday living has as well as the effect they perceive they have with the context.

\subsection{Urban impact evaluation tool}

The tool is a quantitative assessment that confirms statements on different themes. This instrument presents inward and outward occurrences in the living of the residents and the city. There are five major subjects that branch into 15 subtopics with a total of 31 variables:

- Mobility that includes walkability, connectivity, and transportation means.

- Social segmentation that includes social friction and school level.

- Intensitivity that includes population density, dimension, and zoning uses.

- Security that includes most of the variables in the gatedness evaluation tool.

- Basic resources that includes green areas, vegetation type, and public infrastructure.

\subsection{Social impact tool}

As the gatedness assessment tool, this impact values both qualitative and quantitative issues. On the latter the first instrument comes useful, for the reason that most of those variables have a direct relation with social subjects. The quantitative section is complemented with an interview conducted on the same matters. There are seven main aspects that comprise 19 subtopics:

- Gatedness that includes all the variables in the gatedness evaluation tool

- Civic education that includes the school level and the urban signage.

- Ecological consciousness that includes water and wastes management and the vegetation species

- Social Behavior that includes coexistence and social friction variables. 
- Normativity that includes internal regulation and agreements.

- Security that includes both delinquency facts and the perception of inhabitants.

- Urban Image that includes the existence and state of public infrastructure and green spaces, human presence, and urban typology, trace and morphology.

\section{DESIGN APPLICATION FOR THE INTERVENTION}

The design proposal - based on the conclusions drawn from the literature; in addition, to the areas of opportunity resulting in the evaluation tools - approach synthetized, abstracted and combined all these bases. It is essential to propose a solution that promotes coexistence among the whole society [22] and ameliorates the urban and environmental scenario. Therefore, the most conflictive gated neighborhood in León - El Molino Residencial \& Golf - was selected as the area of intervention. With an approximate area of 6,080,000 square meters El Molino Residencial \& Golf is equivalent to the size of 60 Forum Cultural Guanajuato, the major cultural center in the metropolis. Although it only has a population of 113 inhabitant in the $50 \%$ already built area of the community [23].

\subsection{Analysis and diagnosis}

El Molino Residencial \& Golf is an upper-class restricted-access community located in the north sector of the research area in between the protected area of the mountain range - Sierra De Lobos - and the principal body of water - Presa Del Palote - [24] making it an important natural corridor. Its site is next to low income neighborhoods like Alameda de la Presa, Valle de los Castillos and La Lagunita among others; moreover, it shares limits with a development polygon named Popular Maya and is close to one of the largest irregular settlements in León called Los Castillos [24]. It is crucial to keep in mind that "the slums and the gated communities are a profoundly united reality, perpetuating and reinforcing each other's existence" [25]. There are planned only three roads that have or would have access to El Molino Residencial \& Golf putting it in a critical situation in terms of mobility. Right beside the south side of it, is situated the biggest park in the city - Parque Metropolitano - which every year hosts the main hot air balloon festival in Mexico with an estimate of 354 thousand attendees in 2017 [26]. As many others high status residential communities in Mexico, it possesses an entire golf course currently under construction and a country club.

The key problematics that this development owns can be encompassed in mobility, social cohesion and environmental impact. It sounds ironic how the customers knowing this handful of conflicts would be willing to pay around 230,000 USD per lot - this price was obtained in an interview with a real estate agent. The work of sale is straight forward in the sense that it promotes a class-based exclusion and an aspiration for residential segmentation. This latter incentive an undesirable atmosphere. "When this unfairness takes root in the population, it can create a sense of fear, a sense that we don't trust each other. The outcome is that the urban pattern becomes more segregated, more differentiated. This is not socially admirable or economically productive" [2]. As shown on their website, the expected population density of El Molino Residencial \& Golf is anticipated to be about 11.4 house units per hectare, meaning that there would be approximately 6,100 residences in the whole complex. The common reaction of investors facing the conflicts above-mentioned is the introduction of "private infrastructure like "shopping centers, multiplexes, hypermarkets, as well as offices and schools" [4] turning into "artificial alternatives of public spaces" [3]. The neighborhood will count with 30 hectares of first level education institutes, 23.1 hectares of commercial and service areas, and 20 hectares of semi-public parks. All this will be network with 14 


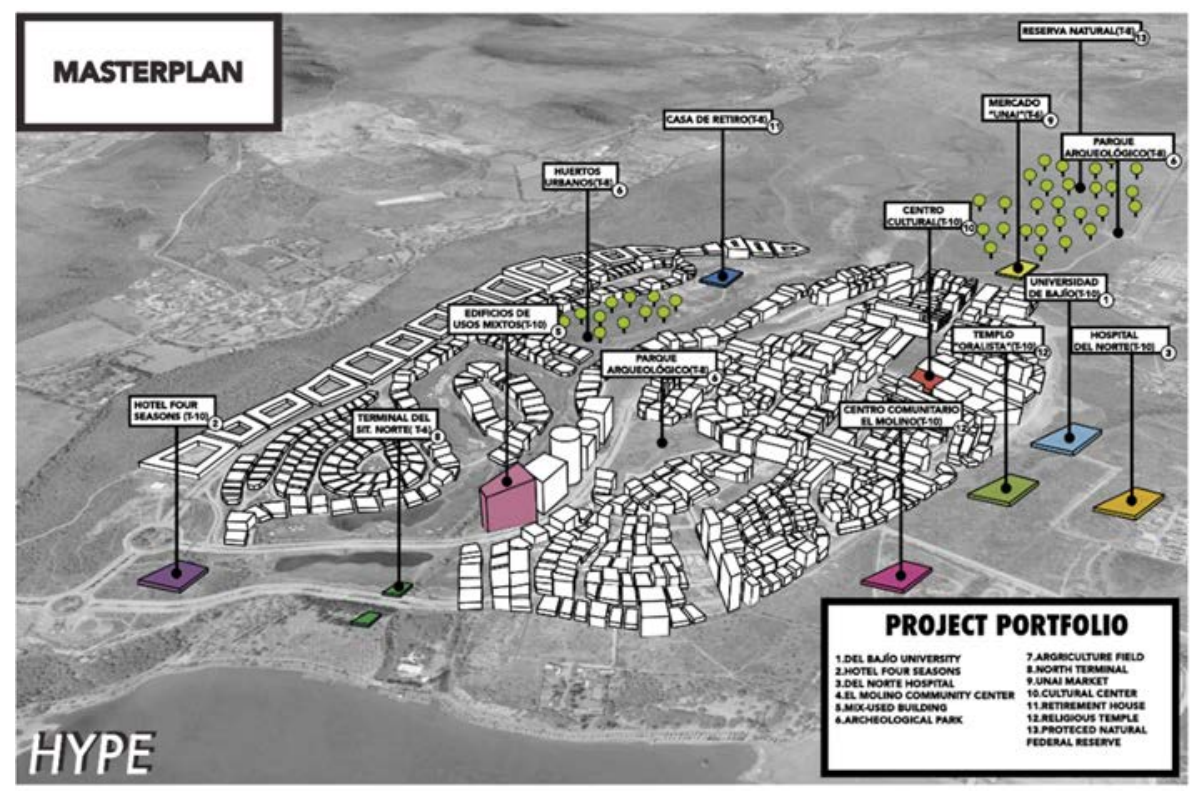

Figure 2: Perspective view of the design proposal masterplan.

kilometers of six lane primary roads. The forecast seeks to create an environment dependent on the golf cart and automobile.

\subsection{Strategies}

The intervention procedure takes the current masterplan of the neighborhood as a canvas to take the proposal to a comprehensive and social cohesive level (Fig. 2). All these tactics present a concrete change in the context with the belief that this kind of transformations would transcend to a social term. There are three main approaches that make intricate crossings to establish a holistic response. Firstly, on the population density, the urban compactness and diversification of land uses all linked to the strengthening of the urban fabric [8] and the utilization of public transportation [6]. When people are spread dispersedly the social interactions cease to happen but when they are put together a significant amount of advantages flow naturally [15]. The second one is about permeability, street life and the intensity of activities in an area. Explained simply by Jacobs "A well-used city street is apt to be a safe street. A deserted city street is apt to be unsafe [27]. The absence of people is usual in roads that interconnect gated communities to the rest of the city. When streets are tightly woven and the space between buildings presents a small scale, the quantity of human contacts increase and so the social relationships [28]. The last method consists in the introduction and ungating of public spaces, an open city concept, and the increase in the supply of public services and infrastructure. An evident bond exists between the will of appropriation, sense of belonging, desire of participation, and the involvement in the maintenance of it. "It seems that our idea as a society is for each family to solve its own housing problem. But this ends up not being the case, due to costs that we pay among all" [29]. The individual life must exit the buildings to become more fulfilling. Public life should end as a constant decision making in urban terms. The mayor's office of Bogotá presented 
the right to the city as a mean and goal in which by creating spaces where social practices could be carried out through self-government and citizen self-management and converge in the strengthening and democratization of public space [30] (Fig. 3).

The public administration in parallel with society has to assure the existence of these places; nonetheless it is "above all the responsibility of all urban citizens to create spaces where collective solutions to common problems can be imagined and realized" [25]. The latter encourages the reason to keep certain features of the original master plan and expand the opportunities of it. Private, public and particular investment is required.

The list of strategies is shown below:

1. The linking of the private primary road system to the rest of the city to facilitate social cohesion and rise connectivity.

2. The diversification of transportation systems and implementation of cycle paths that follow the local administration proposal design of green corridors [31].

3. The completion and widening of the sidewalk network in the neighborhood.

4. The regularization in terms of municipal normativity and signage.

5. The use of diameters of 400-meters as a module to provide basic equipment, promote compactness, walking distances [6], [32] and heterogeneous zoning.

6. The application of the normativity and regulations of urban equipment presented in SEDESOL plans [33].

7. The preservation, dignifying and maintenance of the two archeological zones in the closed community [23].

8. The establishment of a protected natural federal reserve on the north side.

9. The adaptation of the golf course into a compound of urban agricultural fields.

10. The inducement of local and native flora low-maintenance species.

11. The increment in the proportion of green areas per inhabitant to accomplish the World Health Organization objective.

12. The decrease in extent and increase of urban permeability in blocks to promote social interactions [6], [27].

13. The offer of places that support the three levels of trust - in oneself, in other human beings and in institutions - presented by Alain Peyrefitte in Bauman [13].

14. The adoption of a verticality idea in housing, employment and recreational models.e introduction of high intensity mixed-use equipment and zoning.

\section{DISCUSSION}

It is recognized that the research process confronted several limitations in time, economic and human resources to excavate deeper and collect first hand data. Eventhough this effort used qualitative surveys and interviews, the sample size was not big enough to represent a trustworthy analysis. Notwithstanding, the investigation sums up significant evidence that gives support to the intervention proposal and serve as a platform for future information on the subject. The methodology to develop the project presented has the potential to be replicated, escalated and tropicalized. This problematic is current on many nations worldwide and mainly in Latin America. Therefore, the focus implemented in this work would provide several similarities to the one that could be utilized in these countries. It would be needed to continue the research and make an emphasis in two point in particular. The first one would be a compilation of qualitative social research methods to have a reliable and fact-based stance on the matter. The second one is an examination and study in economics, with topics such as the surplus value of housing compared to inflation, and also the true cost that the creation of this sort of infrastructure generates for the city. 


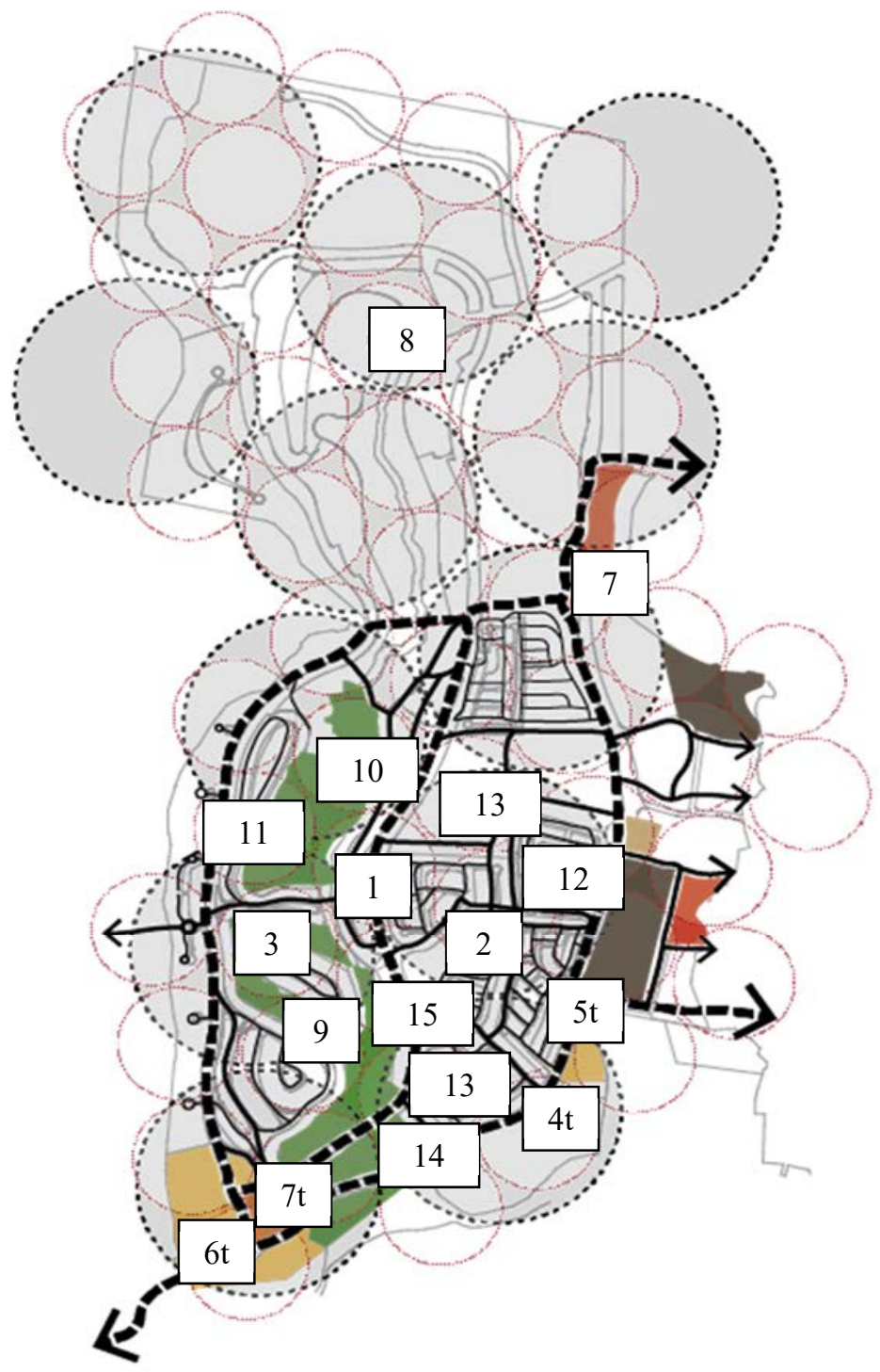

Figure 3: Plan view of the design proposal masterplan with location of the strategies.

\section{CONCLUSION}

Inspired in Bauman's [12]-[14] ideologies: Why are we still trying to solve the insecurity, social frictions and differences, the isolated way of living, the unsustainable practices, the lack of hope in society, and the mediocre lifestyles with what on the first place started this conflicts? Individualism, physical and cultural obstacles, the dependency on exclusive transportation, technology surveillance, hostility and unjustified entitlement have shown to be obsolete and irrational means to transform and progress into a more integrated society. It is needed to change the status quo that pretends to solve socially produced problems with 
one-person approaches [12]. The cooperation of government and society is essential to search and implement solutions that transcend. It should not be expected that the government nor persons carry the whole weight of assuring security [3], bring economic progress and incentive social cohesion development.

To sum up, it has been proved that "Building isolated housing is not building a city. Building walls is not making community" [7]. On the actual state, it has become necessary to deepen the research to find solutions that are economically viable, that bring benefits to the natural environment and in which various groups can support this evolution. It must be encouraged the design of interventions that opens the city in order to transform ourselves and form an inclusive society. While there are a series of crisis, in health, economy, housing, environment and society, the right to the city and the renovation of it has occupied the place of one of the must indispensable and resilient reactions human existence could utilize.

\section{REFERENCES}

[1] Urbanizations and Development Goals: Emerging Futures. World Cities Report 2016; United Nations Human Settlements Programme, 2016. Online. www.unhabitat.org/wp-content/uploads/2014/03/WCR-\%20Full-Report-2016.pdf. Accessed on: 5 May 2018.

[2] Provost, C., Gated communities fuel Blade Runner dystopia and 'profound unhappiness'. The Guardian International Edition, 2014. Online. www.theguardian.com/global-development/2014/may/02/gated-communities-bladerunner-dystopia-unhappiness-un-joan-clos. Accessed on: 5 May 2018.

[3] Pfannenstein, B., Anacleto, E. \& Sevilla, S., ¿La ciudad cerrada y exclusiva? El impacto y la expansión territorial de las urbanizaciones cerradas residenciales en el Área Metropolitana de Guadalajara (México). Presented at Contested Cities, Madrid, Spain, 2016.

[4] Laverde, O., Gated Communities en Latinoamérica. Los casos de Argentina, México, Colombia y Brasil. Revista de Arquitectura, 5, pp. 44-53, 2013. ISSN: 1657-0308.

[5] Diagnóstico Municipal León, Guanajuato. Diciembre 2017; Instituto Municipal de Planeación de León, Guanajuato, 2017. Online. www.implan.gob.mx/downloads/ Diagostico_Municipal_2017.pdf. Accessed on: 1 May 2018.

[6] Charles, C., Gutiérrez, P. Giorgi, E., Gutiérrez, H. \&, Barquero, V., Who decides the city? Mobility, public space, social fabric and wellbeing: Street privatization in Northern León. Entretextos, 9(26), pp 58-74, 2017. ISSN: 2007-5316.

[7] Del Castillo, A., La Guadalajara amurallada domina 14\% de la ciudad. Grupo Milenio, 2017. Online. www.milenio.com/region/Guadalajara-amurallada-domina-ciudadZapopan-Cotos-murtalla-Milenio_Noticias_0_885511475.html. Accessed on: 30 Apr. 2018.

[8] Ferreti, M. \& Arreola, M., Del tejido urbano al tejido social: análisis de las propiedades morfológicas y funcionales. Nova Scientia, No 9 5(1), pp. 98-126, 2012. ISSN: 20070705.

[9] Cabrales, L., Tendencias recientes de las urbanizaciones cerradas y polarización residencial en Guadalajara. Programa en Gestión de la Ciudad, 2006. Online. www.cafedelasciudades.com.ar/carajillo/4_art3.htm\#mexico. Accessed on: 5 May 2018.

[10] Low, S., The edge and the center: Gated communities and the discourse of urban fear. American Anthropology, New Series, 103, pp. 45-58, 2001.

[11] Morales, E., Urban Governance and Residential Privatism: the challenges of managing large-scale gated communities in Mexico. The Sheffield Institute for International 
Development, 2015. Online. www.siid.group.shef.ac.uk/blog/urban-governanceresidential-privatism-challenges-managing-large-scale-gated-communities-mexico/. Accessed on: 16 Apr. 2018.

[12] Bauman, Z., New Frontiers and Universal Values. Public Space, 2004. Online. www.publicspace.org/en/text-library/eng/a025-new-frontiers-and-universal-values. Accessed on: 1 May 2018.

[13] Bauman, Z. Vidas Desperdiciadas. Paidós Ibérica: Barcelona, 2005.

[14] Bauman, Z. Zygmunt Bauman: el individualismo vs el ser social. Online. www.youtube.com/watch?v=PJbf1HXYcD0. Accessed on: 6 May 2018.

[15] Owen, D., Green Metropolis. Why Living Smaller, Living Closer, and Driving Less are the Keys to Sustainability, Riverhead Book: New York, 2009.

[16] SEICA Guanajuato. www.seica.guanajuato.gob.mx

[17] Jaramillo, V., Prevén para León un porvenir difícil. Periódico AM, 2017. Online. www.am.com.mx/2017/08/13/leon/local/preven-para-leon-un-porvenir-dificil-369789. Accessed on: 5 May 2018.

[18] Tun, J., Tendencias de la segregación residencial en León, Guanajuato (1990-2010). Teoría y Praxis, no. 20, pp. 37-67, 2016. DOI: 10.22403/UQROOMX/TYP20/02.

[19] Rizo, H., Crecimiento de mancha urbana, causaría quiebra financiera en León. Grupo Milenio, 2018. Online. www.milenio.com/leon/mancha_urbana-quiebra_financieradesarrollo-milenio-noticias-leon_0_1121887903.html. Accessed on: 30 Apr. 2018.

[20] Directorio Estadístico Nacional de Unidades Económicas; Instituto Nacional de Estadística y Geografía, 2015. Online. www.beta.inegi.org.mx/app/mapa/denue. Accessed on: 6 May 2018.

[21] Cohesión social: balance conceptual y propuesta metodológica; Consejo Nacional de Evaluación de la Política de Desarrollo Social, 2015.

[22] Barrera, A., Asegura cierre de calles perjudica a todos. Periódico AM, 2017. Online. www.am.com.mx/2017/12/20/leon/local/asegura-cierre-de-calle-perjudica-a-todos410194. Accessed on: 6 May 2018.

[23] Inventario Nacional de Vivienda 2016; Instituto de Estadística y Geografía, 2015. Online. www.beta.inegi.org.mx/app/mapa/inv. Accessed on: 5 May 2018.

[24] Plataforma León; Instituto Municipal de Planeación de León, Guanajuato, 2017. Online. www.plataformaleon.gob.mx/. Accessed on: 30 Apr. 2018.

[25] Deneulin, S. \& Maconachie, R., Gated Communities lock cities into cycles of inequality. The Conversation UK, 2014. Online. www.theconversation.com/gatedcommunities-lock-cities-into-cycles-of-inequality-33516. Accessed on 20 Apr. 2018.

[26] Velázquez, F., 354 mil personas asistieron al Festival Internacional del Globo. Noticieros en Línea, 2017. Online. www.noticierosenlinea.com/354-mil-personasasistieron-al-festival-internacional-del-globo/. Accessed on: 6 May 2018.

[27] Jacobs, J., The Death and Life of Great American Cities. Random House, Inc.: New York, pp. 34-35, 1961.

[28] Gehl, J., Life Between Buildings: Using Public Space. Island Press: London, 1987.

[29] Morán, R., Casa propia, problema de todos. Letras libres, 2017. Online. www.letraslibres.com/mexico/economia/casa-propia-problema-todos. Accessed on: 30 Apr. 2018.

[30] Espacio público y derecho a la ciudad. La política del espacio público físico y la venta informal en Bogotá; Alcaldía Mayor de Bogotá. Secretaría Distrital de Gobierno \& UN-Habitat: Bogotá, 2008

[31] Cartera de Programas y Proyectos 2015-2018. Infraestructura y equipamiento para el desarrollo; Instituto Municipal de Planeación, León, Guanajuato, 2015. Online. 
362 Sustainable Development and Planning X

www.implan.gob.mx/downloads/cartera/Infr_y_Equip_para_el_Desarrollo_Cartera de_proyectos_2015-2018.pdf. Accessed on: 23 Apr. 2018.

[32] Espinosa, E., Distancias caminables. Redescubriendo al peatón en el diseño urbano. Trillas: Mexico, 2013.

[33] SEDESOL. www.normateca.sedesol.gob.mx/es/SEDESOL/ 